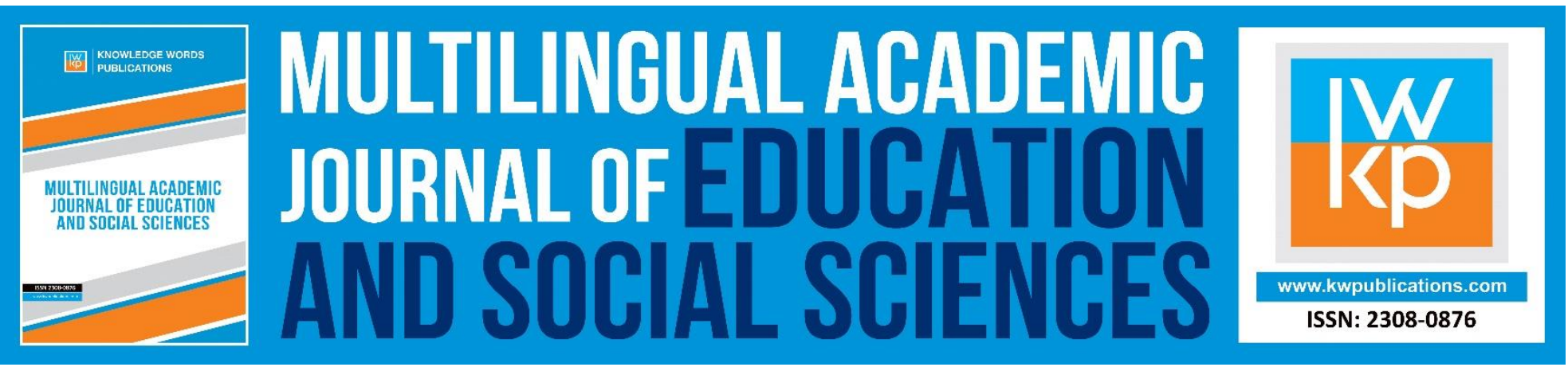

\title{
Ekegusii Subject and Object Markers: Affixes or Clitics?
}

James Mayaka Mboga, Emily Ayieta Ondondo \& David Ogoti Ongarora

To Link this Article: http://dx.doi.org/10.46886/MAJESS/v7-i1/4511

DOI: $10.46886 / M A J E S S / v 7-i 1 / 4511$

Received: 10 April 2019, Revised: 11 May 2019, Accepted: 05 June 2019

Published Online: 28 July 2019

In-Text Citation: (Mboga, Ondondo \& Ongarora, 2019)

To Cite this Article: Mboga, J. M., Ondondo, E. A., \& Ongarora, D. O. (2019). Ekegusii Subject And Object Markers: Affixes or Clitics? Multilingual Academic Journal of Education and Social Sciences, 7(1), 1-19.

\section{Copyright: $\odot$ The Authors 2019}

Published by Knowledge Words Publications (www.kwpublications.com)

This article is published under the Creative Commons Attribution (CC BY 4.0) license. Anyone may reproduce, distribute, translate and create derivative works of this article (for both commercial and non-commercial purposes), subject to full attribution to the original publication and authors. The full terms of this license may be seen at: http://creativecommons.org/licences/by/4.0/legalcode

Vol. 7, No. 1, 2019, Pg. 1 - 19

Full Terms \& Conditions of access and use can be found at https://kwpublications.com/pages/detail/publication-ethics 


\title{
Ekegusii Subject and Object Markers: Affixes or Clitics?
}

\author{
James Mayaka Mboga ${ }^{1}$, Emily Ayieta Ondondo ${ }^{1}$ \& David Ogoti \\ Ongarora ${ }^{2}$ \\ ${ }^{1}$ Department of Linguistics, Languages and Literature, Jaramogi Oginga Odinga University of \\ Science and Technology, Kenya, ${ }^{2}$ Department of Linguistics, Maseno University, Kenya
}

\begin{abstract}
Bantu languages are known for their agglutinative nature and complex verbal morphology. A single verbal complex has several affixes including the subject markers (SMs) and object markers (OMs). The precise status of the SMs and OMs in Bantu remains unresolved. These markers have been analysed as agreement markers in some languages while in others, they are analysed as incorporated pronominals and in other languages as clitics. The objective of this paper is to determine whether these markers should be analysed as agreement markers, incorporated pronominals or clitics in EkeGusii. Findings reveal that the SM is an agreement marker when the overt lexical subject Determiner Phrase (DP) co-occurs with the SM and an incorporated pronoun in null subject constructions. Accordingly, the paper posits that the SM is both an agreeement marker and an incorporated pronominal in EkeGusii. The OM is an incorporated pronominal because the doubling of the OM and the corresponding lexical DP is not licensed in EkeGusii. In analysing the status of SMs and OMs, the morphological and syntactic evidence provided shows that these markers are more of affixes than clitics in this language.
\end{abstract}

Keywords: Status, Subject Marker, Object Marker, Clitic, Incorporated Pronominal, Bantu.

\section{Introduction}

Buell (2005) defines a 'subject marker' as a term used in Bantu linguistic tradition to denote prefixes in the verbal word which agree with a subject NP. The current debate in Bantu revolves around the analysis of the syntactic status of subject markers as to whether they are agreement makers, incorporated pronominals or clitics. According to Bresnan \& Mchombo (1987), the subject marker in Chichewa, for instance, is an ambiguous element between agreement and pronominal.

Additionally, an 'object marker' has been used in Bantu tradition to denote a verbal prefix in the verbal word which agrees with an object DP (either overt or silent) (Buell, 2005). There are other terms which have been used to refer to these markers in the literature and include 'clitic', 'concord', and 'agreement'. Most linguists use these terms (clitic, concord and agreement) 
MULTILINGUAL ACADEMIC JOURNAL OF EDUCATION AND SOCIAL SCIENCES

Vol. 7 No. 1, 2019, E-ISSN: 2308-0876 @ 2019 KWP

neutrally when they do not want to take a position on what they are. For example, Riedel (2009), states that an 'object marker' is a type of morpheme attached to the verb which is referred to as 'object concord' or 'object pronoun' or 'object marker'. Riedel (2009) states that 'object marker' is the most neutral term. Generally in Bantu as well as in EkeGusii, the subject and object markers have received varied interpretations as this paper shows in the following subsections.

The paper is organised as follows. Section 2 gives a brief background of EkeGusii as a Bantu language while section 3 explains the various analyses of SM and OM, that is, agreement markers, incorporated pronominals and clitics. Section 4 elaborates the status of EkeGusii subject markers and section 5 explains the status of EkeGusii object markers. Section 6 concludes the paper.

\section{The Language}

EkeGusii is a Bantu language that is spoken by approximately two and a half million Abagusii people of the present Kisii and Nyamira counties collectively known as Gusii in Kenya (Basweti, Achola, Barasa \& Michira, 2015; Kenya National Bureau of Statistics, 2010). However, EkeGusii is spoken in other areas far from the original EkeGusii speaking region due to migration. Nyakoe, Ongarora and Oloo (2014) assert that although EkeGusii is predominantly spoken in Nyanza province, AbaGusii form part of local immigrants in major towns and cities and it is normal to hear EkeGusii being spoken far from the original EkeGusii speaking areas.

EkeGusii is classified as JE42 by Maho (2008). This language is also classified as an E. 10 language that is spoken in South Western Kenya, the present Kisii and Nyamira counties (Elwell, 2008). According to Nurse and Phillipson (1980), EkeGusii is part of the Eastern sub-group of East Nyanza/Suguti of the Lacustrine Bantu and that it is set apart from other languages in its subgroup such as Kuria, Ngurumi, Zanaki, Shashi, Ikizu and Nata because it has acquired a considerable amount of new non-Bantu lexical items from Dholuo, Maasai, and Kipsigis (a Kalenjin dialect). This is because the Gusii people do not share boundaries with a Bantu speaking community because they are sandwiched between Nilotic speaking communities, that is, Luo, Kipsigis and Maasai (Ogechi, 2006). Therefore, the borrowed lexical items have no relation to the Bantu structure of words.

According to Komenda (2015), most EkeGusii speakers are bilingual in one of the official languages: Kiswahili or English and that due to the proximity of EkeGusii to Nilo-Saharan languages (Dholuo, Kipsigis and Maasai) some speakers are multilingual.

The language exhibits two noticeable dialects, namely EkeRogoro and EkeMaate, elsewhere in the literature called Rogoro and Maate respectively (Ogechi, 2002; Ongarora, 2008; Basweti et al., 2015). The dialects differ in their lexicon and phonology, that is, words for the same item may be different as well as the pronunciation of some words. The Maate dialect is spoken by the clans bordering the Luo and the Maasai ethnic communities. These clans include the Abamachoge and South Mugirango. The Rogoro dialect is spoken by a majority of the speakers who occupy the Kisii central area and the larger Nyamira county. These areas border the Nilotic Luo to the west and Kipsigis (a Kalenjin dialect) to the east (Komenda, 2015; Ongarora, 2008). This paper focused on the Rogoro (Northern) dialect because it is the one which exists in written sources and is the standard dialect (Basweti et al., 2015). 
MULTILINGUAL ACADEMIC JOURNAL OF EDUCATION AND SOCIAL SCIENCES

Vol. 7 No. 1, 2019, E-ISSN: 2308-0876 @ 2019 KWP

\section{Background to the Problem}

Bantu languages, of which EkeGusii is one, are agglutinative in nature with a complex verbal morphology (Ogechi, 2002, 2006; Elwell, 2008). This means that a single verbal word can translate into a sentence in English because several affixes attach to the verb including those marking the subject and the object Noun Phrase (NP) of the sentence. For instance, consider example (1) from Kiswahili adapted from Ogechi (2006).

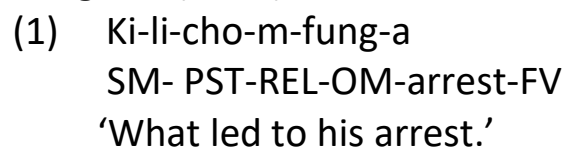

The verbal word in (1) has prefixes marked for different functions. The morpheme ki-marks the subject which in this case can be any noun in class $7, l i$ - marks the past tense, cho- is a relative marker, $m$ - represents the object and $-a$ the final vowel. The result is a sentence whose meaning is context derived as to what led to his arrest. The morpheme cho- is a resumptive pronoun. Ngonyani (2006) defines a resumptive pronoun as a pronominal that appears in a position that is otherwise occupied by a wh-phrase. In the example in (1), cho- appears in a position that is supposed to be occupied by the wh-phrase 'what'. This resumptive pronoun is obligatory as lack of it in a relative clause makes the clause unacceptable as shown in example (2b)

(2) (a) A-li-raru-a ki-tabu ki-li-cho-m-fung-a

SM-PST-tear-FV 7-book 7SM-PST-REL-OM-arrest-FV

'He/she tore the book which led to his arrest.

(b)* a-li-raru-a ki-tabu ki-li-m-fung-a

SM-PST-tear-FV 7-book 7SM-PST-OM-arrest-FV

'He/she tore the book which led to his arrest.

There is an ongoing debate, (Bresnan \& Mchombo, 1987; Diercks, 2010; Riedel, 2009; Kamil, 2006 among others), on the status of subject and object markers in Bantu as to whether subject and object markers should be treated as agreement markers, pronominals or clitics. For instance, Bresnan \& Mchombo (1987) cited in Diercks (2010) argue that the subject marker in Chichewa bears both pronominal and inflectional properties. Diercks (2010) uses this argument and asserts that in Lubukusu, multiple subject markers that may appear within a single clause are not pronominal but realisations of agreement as in example (3) from Diercks (2010).

(3) Ba-ba-andu ba-be-ele ba-soma sii-tabu

2-2-people 2SM-be-PST 2SM-reading 7-book

'People were reading a book.'

The explanation here is that if the subject marker appears twice then it negates the possibility of it being pronominal but marks agreement. Thus for the subject maker to be analysed as an incorporated pronominal it has to appear once. However, Diercks (2010) argues that the object marker in Lubukusu is an incorporated pronominal because it appears once within a clause as realised in example (4).

(4) Tegan a-ba-a-p-ile

1Tegan 1SM-2OM-PST-hit-PST

'Tegan hit them.'

In addition, Riedel (2009) explains this claim by Bresnan and Mchombo that object marking is 'anaphoric agreement' when the object is not overt and 'grammatical agreement' when the object is overt and local, that is, when the object NP is present and comes immediately after the 
MULTILINGUAL ACADEMIC JOURNAL OF EDUCATION AND SOCIAL SCIENCES

Vol. 7 No. 1, 2019, E-ISSN: 2308-0876 @ 2019 KWP

verb. This means that in such analysis all Bantu languages allow 'anaphoric agreement' but not all languages allow 'grammatical agreement'. For Chichewa, Bresnan and Mchombo (1987) claim that object marking is always anaphoric because the object is right dislocated when it appears to double an object marker. They use word order, optionality, tone patterns, objects with in situ wh-questions and relative clauses as evidence for this claim. According to Bresnan and Mchombo, therefore, in Chichewa object marking is always optional unlike in Kiswahili where it can co-occur with the object NP.

Kramer (2012) argues that the status of object markers (OMs), in Amharic has been a subject of debate, on whether they are marked for agreement, or whether they are doubled clitics, that is, pronoun-like morphemes that are somehow associated with the direct object and possibly move to their position near the verb. She takes a position and concludes that in Amharic, the object markers are best classified as doubled clitics because the relation between the object marker and the NP it refers to is only capable of being established if the NP is definite or specific.

In Swahili, Keach (1995), cited in Kamil (2006), argues that the subject marker is ambiguous between being a pronoun and an agreement marker but Kamil (2006) concludes that the subject marker, hereafter SM, in Swahili spoken in Nairobi and its environs, is an agreement marker and not pronominal because it has evolved over time from being a clitic then pronoun and finally an agreement marker. However, he does not raise the question of multiple verb constructions as Diercks (2010) does.

EkeGusii is a highly agglutinative language (Elwell, 2008; Ogechi, 2002, 2006; Ongarora, 2008). This means that the verb root hosts both derivational and inflectional morphemes consequently making the verbal word a grammatical string. The morphemes represent specific grammatical categories or meanings. The affixes that attach to the verb include those marking the subject and the object NPs of the sentence. Consider example (5) below.

(5) A-ka-mo-yo-teb-i-a

SM- PST- OM(IO)-OM(DO)- tell- TRANS- FV

'He told it to him/her.'

The verbal word in (5) has several grammatical positions that appear before the root. These positions include the subject and object markers. As indicated, the subject marker, the direct and indirect object markers are all incorporated in the verbal word.

In EkeGusii noun words consist of a nominal prefix and a stem (Ogechi, 2006; Ongarora, 2008) because Bantu languages are known for their elaborate noun class system in which nouns fall into several genders. In this language, a noun constitutes a class prefix, which may occur with or without an augment, the noun stem and an agent nominalizing suffix in the case of some nouns as in example (6) adapted from Ongarora (2008).

(6) o-mo-rem-i

AUG-NPX-farm-ANS

'A farmer.'

The form of the noun class prefix or part of it occurs as an agreement marker as well as an incorporated pronominal. This means that the noun class prefix mo- in (6) may reappear on the 
MULTILINGUAL ACADEMIC JOURNAL OF EDUCATION AND SOCIAL SCIENCES

Vol. 7 No. 1, 2019, E-ISSN: 2308-0876 @ 2019 KWP

verb or the adjective to mark agreement depending on the class of the noun. This is evident in (7) where the noun belongs to class 3 adapted from Ogechi (2006).

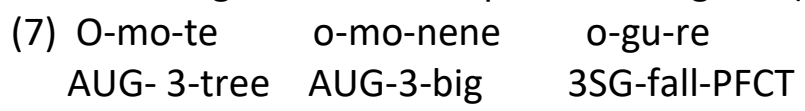

'A big tree has fallen.'

The subject and object NPs are expressed through the use of bound morphemes on the verb terminology that is implied within a given phrase and/or sentence. According to Ongarora (2008), subjects are marked for agreement while objects are marked on the verbal complex as incorporated pronominals as elaborated in example (8).

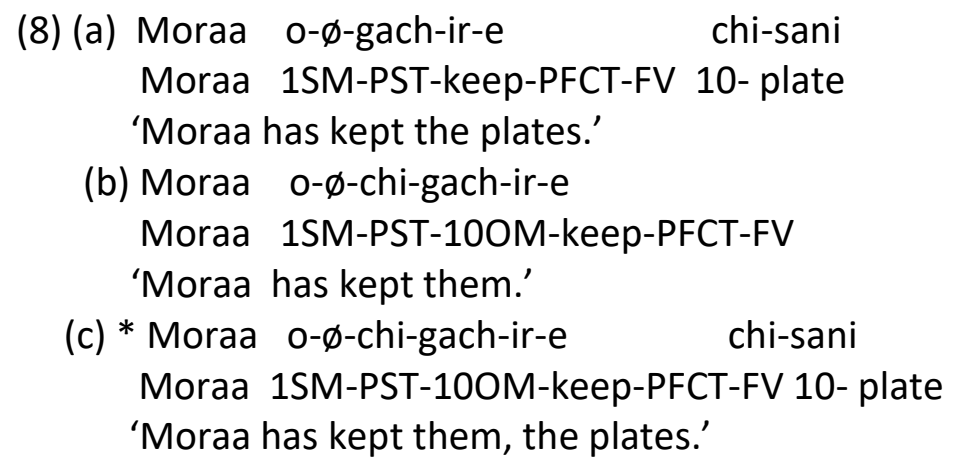

The explanation here is that subject NPs permit doubling by agreement marking as in 8(a) to (c) above while the object NP in (8c) cannot be doubled because the incorporated pronominal and the lexical object NP are in complementary distribution. This means that they co-refer and thus meaningless to repeat one if the other is overt. Therefore, Ongarora (2008) analyses subject markers as agreement markers thus affixes and object markers as incorporated pronominals while Ogechi $(2002,2006)$ analyses these markers as agreement markers as shown in example (9).

(9) Omwenga a-ka-mw-anch-a o-mw-ana

Omwenga 3SM-PST-3OM-like-IND AUG-CL1-child

'Omwenga liked the child.'

In example (9), the SM $a$ - and the OM $m w$ - agree with the subject and object noun phrases respectively. The question whether the object NP and the OM can co-occur is not raised by Ogechi though. These studies (Ogechi 2002, 2006; Ongarora, 2008) thus differ on the analysis of especially the nature of the object markers in EkeGusii.

\section{The Status of EkeGusii Subject Markers}

The subject marker in EkeGusii has been analysed differently as discussed in the following subsections.

\section{The Subject Marker as an Agreement Marker}

Kamil (2006) defines agreement as a process in which two elements that are in local configuration share morphological features through a process of feature matching (or checking). In addition, according to Haspelmath (2002), agreement is a kind of syntactic relation in which the inflectional behaviour of a word or phrase (the target) is determined by the properties of a nominal constituent (controller) to which it relates. The subject marker in EkeGusii is analysed as an 
MULTILINGUAL ACADEMIC JOURNAL OF EDUCATION AND SOCIAL SCIENCES

Vol. 7 No. 1, 2019, E-ISSN: 2308-0876 @ 2019 KWP

agreement marker when the subject marker on the verb agrees with the noun class prefix of the noun as shown in examples (10) and (11).

$$
\begin{aligned}
& \text { (10) e-ri-iso ri-ka-gw-a. } \\
& \text { AUG-5-eye 3sgS-PST-drop-FV } \\
& \text { 'An eye dropped.' } \\
& \text { (11) o-mo-iseke a-rom-et-e o-mw-ana } \\
& \text { AUG-1-girl 3sgS-PST-bite-FV AUG-1-child } \\
& \text { 'A girl bit a child.' }
\end{aligned}
$$

In sentence (10), the subject marker on the verb is the morpheme $r$ - which agrees with the noun class prefix ri- of the noun e-ri-iso 'eye' for class 5, the SM $a$ - in sentence (11) agrees with the prefix for noun class $1 \mathrm{mo}$ - in the noun o-mo-iseke 'girl'. In (11) the subject marker $a$ - and the overt subject DP o-mo-iseke (girl) are local and the subject marker checks agreement features in the verbal word a-rom-et-e as explained in Kamil (2006), the process of agreement involves the sharing of features in this case the number feature of the nouns involved with the subject markers on the verbs thus agreement.

In addition, lorio (2015) argues that if subject markers mark agreement, then doubling of the subject DPs is permitted. This means that, in EkeGusii, when the subject marker and the lexical subject NP co-occur, it is analysed as an agreement marker as exemplified in sentence (12).

(12) e-ge-tabu ge-ka-gw-a

\section{AUG-7-book 7S-PST-drop-FV}

'A book dropped.'

In sentence (12), the subject marker ge-co-occurs with the lexical subject NP e-ge-tabu 'book' and this is said to be doubling. The subject marker therefore is said to agree with the overt lexical subject. Thus under agreement analysis as explained in Bresnan \& Mchombo (1987), the overt subject DP and the subject marker have to be sufficiently local so as to enter into an agreement relation. From example (12), the subject marker ge-cannot be an incorporated pronoun as that would lead to two subjects, that is the lexical subject NP e-ge-tabu and the subject marker ge-, occupying the same position in one clause. This subject marker is instead analysed as an agreement marker because it is local and it checks the agreement features in the verb. Locality refers to the proximity of elements in a linguistic structure (Black, 1999) which means that every argument that an element selects must appear in close proximity to that element. Thus the DP e-ge-tabu selects the subject marker ge-thus locality is achieved.

\section{The Subject Marker as an Incorporated Pronominal}

The subject marker in Bantu can be analysed as a pronoun when it happens to be in null subject constructions (Iorio, 2015; Riedel, 2009). These null subject constructions can either be positive or negative and the lexical subject DP is deduced from the context. According to lorio (2015), every argument that is lexically required needs to be present in the surface structure. This, however, is not the case in null subject constructions. In these constructions, some other overt element must take over the argument function and this is fulfilled by the subject marker acting as an incorporated pronoun as shown in (13).

(13) a-ka-rom-a o-mw-ana 
MULTILINGUAL ACADEMIC JOURNAL OF EDUCATION AND SOCIAL SCIENCES

Vol. 7 No. 1, 2019, E-ISSN: 2308-0876 @ 2019 KWP

3sgS-PST-bite-FV AUG-1-child

'He/she bit a child.'

The subject marker $a$ - in (13) is analysed as a pronoun because it is assumed that the subject DP is dislocated to another position in the sentence. This dislocation therefore negates an agreement analysis because the SM and the lexical subject DP are not local. Sentence (14) shows dislocation of the subject DP.

(14) a-ka-rom-a o-mw-ana, Kemunto

3sgS-PST-bite-AUG-1-child, Kemunto

'She bit a child, Kemunto.'

Example (14) shows the lexical DP Kemunto dislocated to a different position in the sentence, that is, after the object. The SM $a$ - and the DP Kemunto cannot be directly linked (local) thus the SM $a$ - is an incorporated pronominal.

Additionally, the subject marker is analysed as an incorporated pronoun when we have the negation morpheme in the verbal word. In Bantu, as well as in EkeGusii, the negation marker precedes the subject marker as presented in the Bantu verb structure shown in Figure 1.

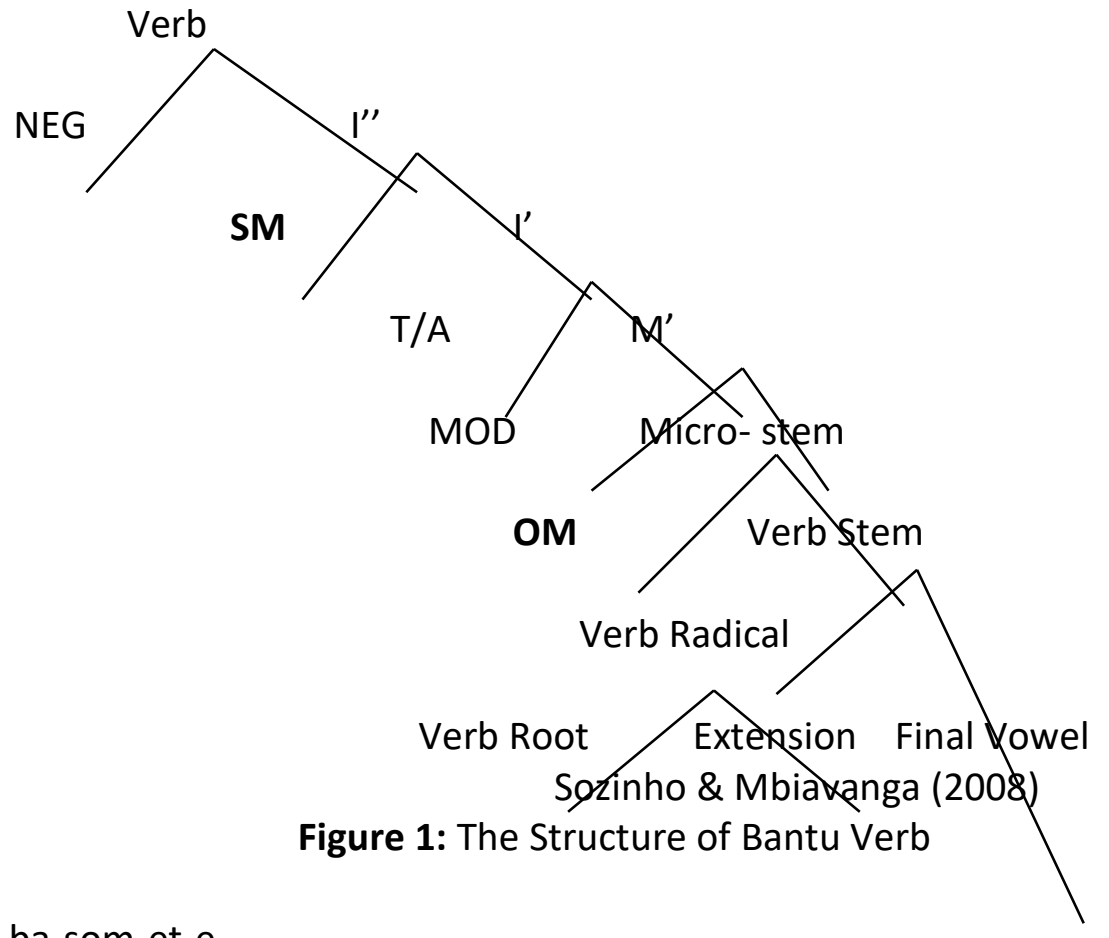

(15) Ti-ba-som-et-e NEG-SM-read-PFC-FV

'They did not read.'

In example (15), the negation marker ti- precedes the subject marker ba- (15) and lorio (2015) argues that in such a case, the subject marker is not properly positioned in the syntactic tree in the same maximal projection [SPEC, TP] thus grammatically disallowed. It therefore follows that when a null subject construction expresses negation, the subject marker is analysed as an incorporated pronominal.

This paper finds that the subject marker in EkeGusii can be analysed as an agreement element when it co-occurs with an overt subject DP on one hand and an incorporated pronominal when it happens to be in a null subject construction, when the subject DP is dislocated and in a 


\section{MULTILINGUAL ACADEMIC JOURNAL OF EDUCATION AND SOCIAL SCIENCES}

Vol. 7 No. 1, 2019, E-ISSN: 2308-0876 @ 2019 KWP

verbal word expressing negation because it comes after the negation morpheme thus not properly positioned syntactically on the other.

After receiving the pronominal analysis, the subject marker receives its $\Theta$-role in its base position inside the VP and then undergoes syntactic movement to a preverbal position, and then combines with the verb via incorporation or cliticization (Zeller, 2007). This implies that the SM is base generated and it occurs in-situ within the VP before it moves and gets to be incorporated in the verbal complex, occupying the first position of the verb. This is head movement to a specifier as shown in Figure 2 (Diercks \& Sikuku, 2013).

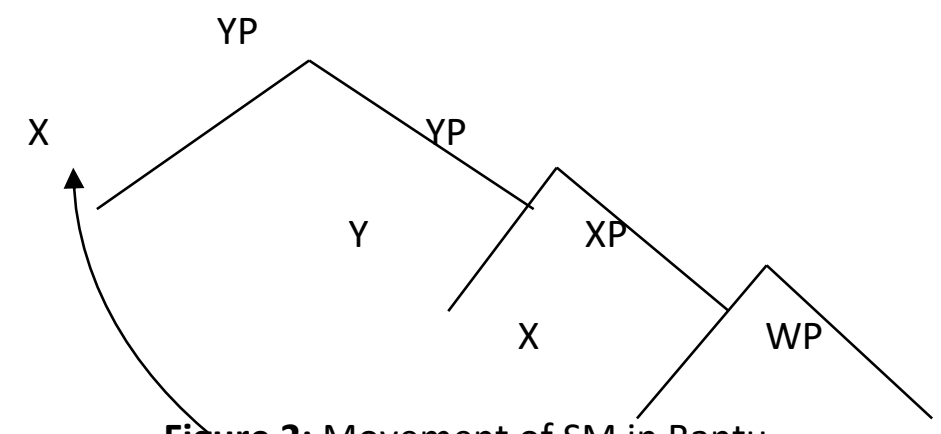

Figure 2: Movement of SM in Bantu

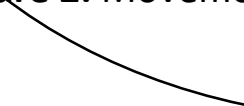

The movement exemplified in Figure 2 above is evident in the EkeGusii example in Figure 3.

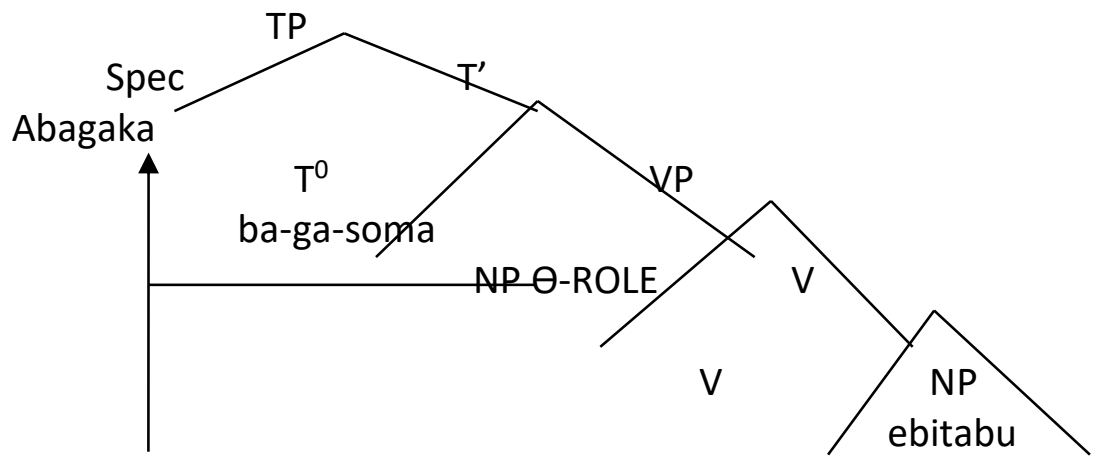

Figure 3: Movement of the Subject from within VP to [SPEC, T]

The subject marker gets incorporated into the verb as an argument and all the arguments of the verb (including the subject) originate within the VP; the VP is selected by a functional 
MULTILINGUAL ACADEMIC JOURNAL OF EDUCATION AND SOCIAL SCIENCES

Vol. 7 No. 1, 2019, E-ISSN: 2308-0876 @ 2019 KWP

head (for tense), which provides the landing site for verb movement in Bantu (Zeller, 2007).

This movement is exemplified using example (16).

(16) A-ba-gaka ba-ga-som-a e-bi-tabu

AUG-2-old men 2S-PST-read-FV AUG-8-book

'The old men read books.'

It can therefore be concluded that subjects in EkeGusii are represented as syntactic constituents in the verbal word by the subject markers thus pronominal interpretation.

\section{The Status of EkeGusii Object Markers}

The object marker in Bantu as well as in EkeGusii has been analysed as an agreement marker, an incorporated pronominal as well as a clitic as explained in the following subsections.

\section{The Object Marker as an Agreement Marker}

In Bantu morphology, the object marker is analysed as an agreement marker if it doubles the lexical object DP (Riedel, 2009). Contrastively, in EkeGusii, doubling of the OM and the corresponding lexical DP is grammatically disallowed (Ongarora, 2008) as both are in complementary distribution as shown in (17).
*Moraa a-ka-ri-riik-a
ri-rube
1Moraa 3sgS- PST-5OM-write-FV 5-letter

1Moraa wrote it (a letter).

Example (17) above is disallowed because the object marker ri- doubles the lexical object rirube 'letter' and thus repeats the syntactic function of the object in the verb that has already been expressed by the object. Therefore, the object marker in EkeGusii cannot be analysed as an agreement marker though it agrees with the referent.

Riedel (2009) argues that in Bantu languages most diagnostics in the literature are not helpful in determining the status of object markers since they yield contradictory results. She however claims that a general analysis of Bantu object marking is agreement morphology, a position that may not apply to many Bantu languages, EkeGusii included. Riedel argues that once a language shows one instance of doubling, it should be analysed as being an agreement language. Doubling is when the object marker co-occurs with the corresponding object DP as shown in the Kiswahili example in (18).

(18) Mwalimu a-li-m-chap-a m-toto

1 teacher 3sgS-PST-OM-beat-FV 1-child

'A teacher beat a child.'

In example (18), the object marker m- doubles the lexical object DP mtoto 'child' and the object marker $\mathrm{m}$ - moves to the verb to check agreement features in the verb. Thus in Kiswahili the object marker is an agreement marker (Kamil, 2006; Iorio, 2015) a case which is different in EkeGusii as shown in example (17). In EkeGusii, doubling does not occur because the object originates from the VP as shown in Figure 4. 
MULTILINGUAL ACADEMIC JOURNAL OF EDUCATION AND SOCIAL SCIENCES

Vol. 7 No. 1, 2019, E-ISSN: 2308-0876 @ 2019 KWP

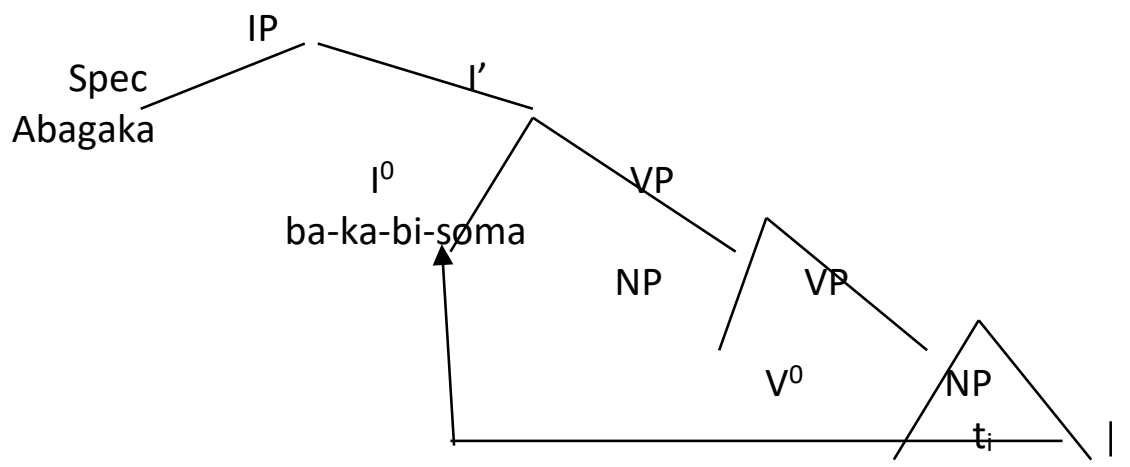

Figure 4: Movement of the $\mathrm{OM}$ to $\mathrm{I}^{0}$

As shown in Figure 4, the object DP e-bi-tabu moves from within VP to $\mathrm{I}^{0}$ thus cannot cooccur because both the $\mathrm{OM}$ and the lexical object DP are in complementary distribution. It therefore follows that in EkeGusii, the object marker is not an agreement marker because the OM and lexical object DP do not double.

\section{The Object Marker as an Incorporated Pronominal}

An analysis of object markers as incorporated pronouns rules out the co-occurrence of an OM and a postverbal object (because the OM originates as the object of the verb and incorporates into the verb itself) (Diercks et al., 2013). In addition, lorio (2015) argues that if object markers cannot double a lexical object locally, that is, when they are in complementary distribution with lexical objects with regard to the inflectional domain, then they should be analysed as incorporated pronominals. In EkeGusii, Ongarora (2008) asserts that the object marker is an incorporated pronoun because it is in complementary distribution with the lexical object DP and the object marker cannot double the lexical object DP as exemplified in (19) below.

(19) Bogonko a-ka-mo-ram-a

1Bogonko SM-PST-OM- abuse-FV

'Bogonko abused him/her.'

In (19), the object marker mo- originates as the object of the verb rama 'abuse' and therefore it cannot co-occur with the lexical object DP, that is, in noun class 1 thus an incorporated pronoun. However, the doubling of the object marker and the overt lexical object DP cannot be generalised to all Bantu languages because they behave differently. Kiswahili, for instance, as shown in example (18) allows the syntactic doubling that is disallowed in EkeGusii. Thus each language has to be analysed as its data allows.

Additionally, the object marker in EkeGusii can also be analysed as an incorporated pronominal when the wh-phrase is considered. In this case, EkeGusii does not allow the wh-phrase to cooccur with the object marker as explained in Bresnan \& Mchombo (1987) who argue that the whphrase cannot co-occur with OMs because they indicate a topic status of the co-referring lexical object as realised in sentence (20).

(20) (a) Ningo o-gany-et-e?

Who 2sgS-wait-PRT-FV

'Who are you waiting for?'

(b) *Ning'o o-mo-gany-et-e?

Who 2sgS-OM-wait-PRT-FV 
MULTILINGUAL ACADEMIC JOURNAL OF EDUCATION AND SOCIAL SCIENCES

Vol. 7 No. 1, 2019, E-ISSN: 2308-0876 @ 2019 KWP

'Who are you waiting for?'

Example $(20 \mathrm{~b})$ is unacceptable because the verbal word contains an object marker mowhich cannot co-occur with the wh-word ning'o. Thus based on this argument, the object marker is analysed as an incorporated pronominal in EkeGusii.

\section{The Object Marker as a Clitic}

Before it is established whether object markers in EkeGusii are clitics or not, it is prudent to explore the differences between affixes and clitics as proposed by Zwicky \& Pullum (1983). Zwicky and Pullum come up with six criteria to distinguish these elements and they are analysed below in relation to EkeGusii facts.

Firstly, elements called clitics are not restricted as to the host they can attach to (Kari, 2002). While affixes may attach to a defined set of hosts, clitics are freer than affixes as far as the selection of the host is concerned. As such, EkeGusii subject and object markers are known to attach to verbs only as shown in (21) while noun class prefixes attach themselves only to nouns as exemplified in (22) below.

(21) A-ka-ba-rom-a

3sgS-PST-3plO-bite-FV

'He/she bit them.'

(22) O-mo-te e-me-te

AUG-3-tree AUG-4-tree

Tree trees

As shown in (21) the subject marker $a$ - and the object marker $b a$ - have been attached to the verb root roma 'bite' while the class prefixes mo- and me- in (22) are attached to the noun root -te 'tree' and any other noun in the relevant noun class.

Possession in EkeGusii can be marked through the preposition 'of' whose form is $-a$ and which changes as per the noun class of the noun in which it appears. This possessive preposition may appear as a clitic when it is contracted especially when the vowels are the same. This is exemplified in (23) and (24) where the possessive preposition ba changes to bo before attaching to the noun. One of the vowels is deleted thus the contracted form as shown in (23) and (24).

(23) a-ba-somba b'o-mo-nene

AUG-2-servant possessive AUG-1- lord

'The lord's servants.'

(24) a-ba-teri b'o-go-tog-i-a o-mo-nene

AUG-2-singer for AUG-15-praise-APPL-FV AUG-1-lord

'Singers for praising the Lord.'

The clitic element $b^{\prime}$ in (23) is attached to a noun omonene 'lord' while the clitic element $b$ ' in (24) is attached to a verb togia 'praise'. Under this criterion therefore, the subject and object markers are affixes and not clitics because they attach themselves to verbs only.

The second criterion is that semantic idiosyncransies are not characteristic of clitics (Holmstedt, 2012). Holmstedt defines the term idiosyncrasy as the uniqueness with which the clitics (or any syntactic element) can be identified. This means that when clitics attach to a host, the result is predictable, for instance the English 've has the same meaning in 'They've and 'I've'. 
MULTILINGUAL ACADEMIC JOURNAL OF EDUCATION AND SOCIAL SCIENCES

Vol. 7 No. 1, 2019, E-ISSN: 2308-0876 @ 2019 KWP

In EkeGusii, full and reduced forms of clitics have the same meaning as the examples in (25a-f) show.

$$
\begin{gathered}
\text { (25)(a) e-nyomba ya o-mo-somba } \\
\text { 9-house of AUG-1-slave. } \\
\text { 'A slave's house.' } \\
\text { (b) e-nyomba y'o-mo-somba } \\
\text { 9-house of AUG-1-slave } \\
\text { 'A slave's house.' }
\end{gathered}
$$

(c) o-mo-iseke bw'o-mo-nto

AUG-1-girl POSS AUG-1-person

'A person's girl.'

(d) e-ri-iso ri'o-mo-nto

AUG-5-eye POSS AUG-1-person

'A person's eye.'

(e) e-me-te y'o-mo-nto

AUG-4-tree POSS AUG-1-person

'A person's tree.'

(f) e-bi-oto bi'o-mo-nto

AUG-8-frog POSS AUG-1-person

'A person's frogs.'

As realised in examples (25) (a) to (f), the semantic realisation in the sentences is the same, that is, they are all allomorphs that mark possession.

In contrast, affixes may combine with a host to produce a complex word with an unpredictable meaning because they have semantic uniqueness as per class and number as examples in (26a-e) show for subject markers.

(26) (a) o-mo-iseke a-ga-kw-a

AUG-1-girl S-PST-die-FV

'A girl died.'

(b) a-ba-taata ba-ga-kw-a

AUG-2-father S-PST-die-FV

'Fathers died.'

(c) o-mo-te o-ga-kw-a

AUG-3-tree S-PST-die-FV

'A tree died.'

(d) e-ri-iso ri-ga-kw-a

AUG-5-eye S-PST-die-FV

'An eye died.'

(e) e-bi-oto bi-ga-kw-a

AUG-8-frog S-PST-die-FV

'Frogs died.

As shown in (26) (a) to (e) above, when attached to the verb $k w$-a 'die' the subject markers are different as per each noun class. The object markers have also the semantic uniqueness as shown by the examples in (27a-e), a case that does not happen with clitics. 
(27) (a) a-ka-mo-it-a

SM-PST-1OM-beat-FV

'He/she beat him/her.'

(b) a-ka-ba-it-a

SM-PST-2OM-beat-FV

'He/she beat them.'

(c) a-ka-yo-it-a

SM-PST-3OM-beat-FV

'He/she beat it.'

(d) a-ka-ri-it-a

SM-PST-5OM-beat-FV

'He/she beat it.'

(e) a-ka-bi-it-a

S-PST-8OM-beat-FV

'He/she beat them.'

The object markers in (27) (a) to (e) show semantic uniqueness according to the noun class they belong to.

The third criterion used to distinguish affixes from clitics is that affixes are morphologically idiosyncratic in that they affect the host word in an unexpected way as shown in (28).

(28) a-ba-sacha ba-ga-kw-a

AUG-2-man 3pIS-PST-die-FV

'Men died.'

The subject marker $b a$ - in (28) above uniquely affects the verb $k w$ - 'die' in the sense that the verbal root $k w$-has more morphemes which represent different morphological categories in this case ba- represents noun class morphology and number morphology. Such a morpheme is a portmanteau morpheme because it explains more than one morphological category. Contrastively, morphological idiosyncrasies are not characteristic of clitics (Kari, 2002). This means that the attachment of clitics does not affect the host word morphologically. Thus a clitic does not alter the internal morphology of a word as exemplified in (29).

(29) e-nyomba y'o-mo-sacha

9-house POSS-AUG-1-man

'A man's house.'

In example (29), the clitic element y' does not morphologically affect the host o-mo-sacha 'man'. According to this criterion therefore, EkeGusii subject and object markers are affixes and not clitics.

The fourth criterion holds that a clitic and host combination is not subject to syntactic rules, whereas words exhibiting affixation are treated as single syntactic items (Kari, 2002; Holmstedt, 2012). This implies that syntactic rules treat affix-word combinations as a single syntactic unit in (30).

(30) (a) Monyoro a-ka-mo-ror-a 1Monyoro SM-PST-OM-see-FV

'Monyoro saw him.' 
MULTILINGUAL ACADEMIC JOURNAL OF EDUCATION AND SOCIAL SCIENCES

Vol. 7 No. 1, 2019, E-ISSN: 2308-0876 @ 2019 KWP

(b) Monyoro a-ka-ba-ror-a

1Monyoro SM-PST-2OM-see-FV

'1Monyoro saw them.'

(c) Monyoro a-ka-ri-ror-a

1Monyoro SM-PST-5OM-see-FV

'1Monyoro saw it.'

Examples (30) (a) to (c) show that there are syntactic rules that govern the combination of the subject and object markers to the verbs according to the noun classes to which the nouns belong. For (30) there are syntactic rules that come into play, that is, there has to be class agreement of the subject marker and other elements within the verb. This is different as shown with clitic-host combinations in (31) (a) and (b).

(31)(a) e-gutwa y'o-mo-twe

9-crown POSS AUG-3-head

'A head's crown.'

(b) a-ma-chiko y'e-nse

AUG-6-law POSS AUG-country

'A country's laws.'

As examples (30) (a) to (c) show, the combination of the SM, OM and the verb root giving rise to a single verbal words a-ka-mo-ror-a, $a$-ka-ba-ror-a and $a$-ka-ri-ror-a, cases which are different in (31) where $y^{\prime}$ omotwe and $y^{\prime} e$-nse cannot be treated as a single units. In both cases in (31) the elements $y^{\prime}$ cannot be syntactically analysed with their hosts omotwe 'head' and ense 'country' respectively. It therefore follows that as per this criterion, the subject and object markers in EkeGusii are affixes and not clitics.

Kari (2017) gives general characteristics of an affix as an element that attaches itself to another linguistic unit called a stem for the sole purpose of gaining morphological identity; it cannot be deleted but can be moved along with its stem to a different location in the sentence and its meaning is determined with respect to the stem. Following this definition, EkeGusii subject and object markers as shown in example (30) (a) to (c) are affixes because they attach to stem to get morphological identity since they cannot stand on their own; They cannot be deleted because they are integral parts of the words; They always move along with their stems to different locations in the sentence and their meanings are subject to the different noun classes that they belong.

As regards clitics, Kari (2017) sets the standard that an element called a clitic attaches itself to gain phonological identity, it may be deleted but cannot be moved along with its host to a different location has a constant meaning irrespective of its form or the kind of host it attaches to. The elements that can fit in this definition are in examples (25) (a) to (f) in which they depend on their host for phonological identity; they may be deleted but they cannot be moved with the host to a different position in the sentence and their meaning is constant because they mark possession irrespective of the different forms they take, that is, $b w^{\prime} r i^{\prime} b i^{\prime}$ respectively. The subject and object markers are thus affixes and not clitics

With the explanation on the differences between affixes and clitics in the preceding subsection we now turn to other perspectives that have been advanced on the analysis of these markers. It has to be remembered that elements called clitics form a mixed bunch and what is exactly referred to as a clitic varies from one study to another (Halpern, 2001). Halpern (2001) 
presents two perspectives from which clitics can be defined. The first is the prosodic one in which a clitic is any prosodically weak element which is not a canonical inflectional or derivational affix. In this case, the clitic depends on a host for its pronunciation as shown in (32).

(32) e-nyongo y'o-mo-ng'ina

9-pot POSS AUG-1-woman

'A woman's pot.'

In (32), the form with the apostrophe ( $\left.y^{\prime}\right)$ shows that it is prosodically attached to the host noun o-mo-ngina 'woman'. Its full form syntactically is ya. Following this perspective, EkeGusii subject and object markers are not clitics but affixes because they largely do not prosodically attach to the verbal words which are their hosts instead they are part of the verb and can never be seen to occur in isolation in this language. Affixes never behave this way in EkeGusii because they can never be contracted for instance $m^{\prime}$ instead of $m o$ in (33).

(33) *Monyoro a-ka-m'-ror-a

Monyoro SM-PST-OM-see-FV

'Monyoro saw him/her.'

The second perspective shows that object markers can be analysed as clitics if they are morphemes which syntactically function as independent words (Labelle, 2008). The basic arguments for a clitic analysis of Bantu object markers therefore are that these markers bear some degree of morphosyntactic independence and they are distinguished from morphemes that are simply affixal elements (Diercks \& Sikuku, 2013). In this case, object markers are taken to syntactically function as independent words in the verbal complex. This is the syntactic definition of the term clitics as example (34) shows.

(34) Mokua a-ka-ye-butor-a

1Mokua SM-PST-OM-cut-FV

'Mokua cut it.'

For this reason it can be argued that object markers in EkeGusii are clitics just like in other Bantu languages (Diercks \& Sikuku, 2013). Being clitics these markers are not just affixal elements but they are between affixes and pronouns as example (34) above shows. Object markers in EkeGusii can be analysed as representing their corresponding lexical object DPs in the verbal word. Thus if they are compared to negation markers (see Figure 1 for the order of morphemes in the Bantu verb), for instance, they have higher syntactic importance as example (35) shows.

(35) Ti-ba-ge-som-et-i

NEG-3sgS-7OM-read-PST-FV

'They did not read it.'

Apart from being an affix (a morpheme in the verbal template), the object marker ge- in (35) is also syntactically an argument because it represents the syntactic object DP in the verbal word. For this reason therefore, the object marker is a syntactic clitic.

\section{Conclusion}

In sub-sections 1 to 5 above, the status of EkeGusii subject and object markers has been discussed. It has been established that the subject marker can be analysed as an agreement marker when there is doubling of the lexical subject DP and the subject marker. This is in relation 
MULTILINGUAL ACADEMIC JOURNAL OF EDUCATION AND SOCIAL SCIENCES

Vol. 7 No. 1, 2019, E-ISSN: 2308-0876 @ 2019 KWP

to the locality constraints which dictate that the lexical subject DP (which is mostly obligatory) and the subject marker have to be locally available for the agreement features to be matched.

It has also been realised that the subject marker is an incorporated pronoun in EkeGusii null subject constructions. In this case, it is argued that the subject marker is a pronoun because the overt lexical subject DP and subject marker occupy the same syntactic position thus their roles cannot be repeated. Thus the lexical subject DP is a topic as proposed by Kamil (2006). Therefore, the SM is both an agreement marker as well as an incorporated pronominal.

The object marker has also been analysed as an agreement marker when there is doubling which takes place when the object marker co-occurs with the corresponding object DP. However, this syntactic phenomenon of doubling is grammatically disallowed in EkeGusii. The object marker in EkeGusii is thus analysed as an incorporated pronoun even though it marks agreement. In addition, the object marker in EkeGusii is analysed as an incorporated pronoun in wh-phrases because the OM cannot co-occur with wh-phrases.

The syntactic behaviour of subject and object markers in EkeGusii have been analysed using the six criteria set by Zwicky \& Pullum (1983). It has been realised that according to the criteria, EkeGusii subject and object markers are affixes and not clitics.

Additionally, object markers can be analysed as clitics. Clitics in this syntactic context are elements which have morphosyntactic independence and they are not just affixal elements but are between affixes and pronouns. These markers represent the lexical object DPs in the verbal word and are thus taken to be weak pronouns which have syntactic independence rather than basic morphemes thus the clitic analysis.

Due to the foregoing evidence, this study finds that EkeGusii SMs are both agreement markers and incorporated pronominals thus affixal in nature. EkeGusii OMs, on the other hand are both agreement markers, incorporated pronominals and clitics.

\section{References}

Basweti, N. O., Achola, E. A., Barasa, D., \& Michira, J. N. (2015). Ekegusii DP and its Sentential Symmetry: A Minimalist Inquiry. In International Journal of Language and Linguistics. Vol 2, No 2, 93-107.

Black, C. A. (1999). A step-by-step introduction to the government and binding theory. Summer Institute of Linguistics.

Bresnan, J., \& Mchombo, S. (1987). Topic, pronoun and agreement in Chichewa. Language 63: 741-782.

Buell, L. C. (2005). Issues in Zulu verbal morphosyntax. Unpublished doctoral dissertation. University of California: Los Angeles.

Diercks, M., \& Sikuku, J. (2013). Object clitics in a Bantu language: deriving pronominal incorporation in Lubukusu. Moi University and Pomona College.

Diercks, M. (2010). Agreement with subjects in Lubukusu. Unpublished PhD dissertation. University of Georgetown: Washington D.C.

Diercks, M., Ranero R., \& Paster, M. (2013). Evidence for a clitic analysis of object markers in Kuria.

Elwell, R. (2008). Finite state methods for bantu verb morphology. CSLI publications.

Halpern, A. (2001). "Clitics" The handbook of morphology. Spencer, Andrew and Arnold M. Zwicky (eds). Blackwell Reference Online. 
MULTILINGUAL ACADEMIC JOURNAL OF EDUCATION AND SOCIAL SCIENCES

Vol. 7 No. 1, 2019, E-ISSN: 2308-0876 @ 2019 KWP

Haspelmath, M. (2002). Understanding morphology. Oxford University Press: New York. Holmstedt, R. D. (2012). Clitics.

Iorio, D. E. (2015). Subject and object marking in Bembe. Unpublished Doctoral dissertation. University of Newcastle: Newcastle.

Kamil, U. D. (2006). Subject agreement in Nairobi Swahili. Selected Proceedings of the 35th Annual Conference on African Linguistics, ed. John Mugane et al., 225-233. Somerville, MA: Cascadilla Proceedings Project.

Kari, E. E. (2002). Distinguishing between clitics and affixes in Degema, Nigeria. African Study Monographs, 23(3): 91-115.

Kari, E. E. (2017). On the Status of Subject Markers in African Languages. Studies in Linguistics 44, 99-134.

Kenya National Bureau of Statistics, (2010). 2009 Population and housing highlights. Available at http://www.knbs.or.ke/Census Results/KNBS Brochure.pdf Accessed Sep 3, 2014.

Komenda, S. (2015). The nature of vowel length in Ekegusii: A theoretical account. In International Journal of Education and Research. Vol. 3 No. 9, 1-14.

Kramer, R. (2012). Differentiating agreement and doubled clitics: Object markers in Amharic. Selected Proceedings of the 41st Annual Conference on African Linguistics, ed. Bruce Connell and Nicholas Rolle, 60-70. Somerville, MA: Cascadilla Proceedings Project.

Labelle, M. (2008). Pronominal object markers in Bantu and Romance. In De Cat C \& Demuth K. (eds). The Romance-Bantu connection. Amsterdam: Benjamins, pp 83-109.

Maho, J. (2008). The Bantu bibliography (African linguistic bibliography). Koln: Rudiger Koppe Verlag.

Ngonyani, D. S. (2006). Resumptive pronominal clitics in Bantu languages. Selected Proceedings of the $36^{\text {th }}$ Annual Conference on African Linguistics, ed. Olaoba F. Arasanyin and Michael A. Pemberton, 51-59 MA: Cascadilla Proceedings Project.

Nurse, D., \& Phillippson, G. (1980). Bantu Languages of East Africa. In E. C. Polomé \& C. P. Hill (Eds.), Language in Tanzania (pp. 26-67). London: Oxford University Press.

Nyakoe, D., Ongarora, D., \& Oloo, P. (2014). An analysis of the food metaphor in EkeGusii HIVand AIDS discourse. In: International Journal of Academic Research in Business and Social Sciences. Vol. 4. No.1, 221-228.

Ogechi, N. O. (2002). Trilingual codeswiching in Kenya- Evidence from Ekegusii, Kiswahili, English and Sheng. Unpublished Doctoral dissertation. Hamburg

Ogechi, N. O. (2006). Language and its usage in J.S. Akama \& R.,Maxon (eds), Ethnography of the Gusii of Western Kenya: A Vanishing Cultural Heritage. New York: The Edwin Press Limited.

Ongarora, D. O. (2008). Bantu morphosyntax: A study of EkeGusii. Unpublished PhD Thesis. Jawaharlal Nehru University.

Riedel, K. (2009). The syntax of object marking in Sambaa. A comparative Bantu perspective. PhD dissertation, University of Leiden.

Sozinho, M., \& Mbiavanga, F. (2008) A preliminary exploration of verbal affix ordering in Kikongo, a Bantu language of Angola. In Language Matters: Studies in the languages of Africa, 39:2,332-358, DOI 10.1080/10228190802596589.

Zeller, J. (2007). On the subject marker in Kinyarwanda. Selected proceedings in Annual Conference of the Linguistic Society of Southern Africa in Potchefstroom.

Zeller, J. (2012). Object marking in Zulu. Durban: University of KwaZulu - Natal. 


\section{MULTILINGUAL ACADEMIC JOURNAL OF EDUCATION AND SOCIAL SCIENCES}

Vol. 7 No. 1, 2019, E-ISSN: 2308-0876 @ 2019 KWP

Zwicky, A. \& Pullum, G. (1983). Cliticization vs inflection: English n't. Language 59, 502-513. 